\title{
PENGEMBANGAN IDENTITAS \\ REMAJA TRANSMIGRAN JAWA DI LAMPUNG MELALUI PERTEMANAN ANTAR BUDAYA DI SEKOLAH
}

\author{
Nina Yudha Aryanti \\ Jurusan Ilmu Komunikasi, FISIP Universitas Lampung
}

\begin{abstract}
ABSTRAK
Pertemanan antarbudaya remaja di sekolah secara umum beperan untuk mendukung pengembangan identitas diri, tetapi belum maksimal untuk mendukung pengembangan identitas etnik remaja. Penelitian ini dilakukan untuk mengetahui dan menganalisa peranan pertemanan antarbudaya remaja dalam pengembangan identitas diri dan identitas etnik. Melalui penelitian kualitatif diperoleh hasil bahwa (1) remaja memiliki dua konteks relasi pertemanan antarbudaya dengan sepuluh tema interaksi yang berperan dalam pengembangan identitas diri; (2) terkait pengembangan identitas etnik, remaja berada dalam tahapan unexamined identity, yang menempatkan identitas etnik bukan sebagi prioritas dalam pertemanan antarbudaya di sekolah.
\end{abstract}

Kata-kata kunci: Pertemanan antarbudaya, remaja, sekolah, identitas diri, identitas etnik

\section{THE DEVELOPMENT OF JAVANESE TRANSMIGRANTS ADOLESCENT IDENTITY IN LAMPUNG THROUGH INTERCULTURAL FRIENDSHIP AT SCHOOL}

\begin{abstract}
The intercultural peer group at school has roles to support the development of self identity. But, it still has limited to support to develop ethnic identity. The purpose of this research is to analyze the role of intercultural peer group at school to support the development of self identity and ethnic identity. This qualitative research concludes that: (1) adolescence has two relation contexts with ten interaction themes that support development of self identity and ethnic identity; (2) Adolescence has unexamined identity level of development. Its show that considers ethnic identity is not a priority inan intercultural peer group at school.
\end{abstract}

Key words: Intercultural peer group, adolescence, school, self identity, ethnic identity

Korespondensi: Nina Yudha Aryanti. Jurusan Ilmu Komunikasi, FISIP Universitas Lampung, Jl. Sumantri Brojonegoro 1 Bandar Lampung. Email: nina_idha@yahoo.co.id 


\section{PENDAHULUAN}

Perkembangan persebaran etnik Jawa di Lampung dimulai sejak kolonisasi di tahun 1905 oleh Belanda. Kondisi ini mengakibatkan adanya pembauran etnik lintas generasi di Lampung. Hal lain yang juga muncul, yaitu etnik Jawa di Lampung mengalami akulturasi dan pergeseran budaya. Dalam banyak kasus dijumpai generasi transmigran keturunan etnik Jawa merasa sudah tidak memiliki ciri identitas dari daerah asalnya, bahkan terputus dengan leluhurnya. Secara singkat kondisi ini menyumbangkan permasalahan bagi keturunan transmigran jawa dalam mencari identitas etnik dan identitas budayanya, terlebih lagi apabila keturunan etnik Jawa ini adalah remaja.

Permasalahan identitas keturunan etnik Jawa di Lampung sering muncul apabila dihadapkan pada individu atau kelompok lain yang dianggap berbeda budaya. Ciri identitas budaya Jawa di Lampung yang mulai memudar menjadi kendala tersendiri bagi remaja dalam pembentukan dan pengembangan identitas etnik. Kondisi remaja yang belum memahami sepenuhnya tentang budaya yang disosialisasikan di keluarga dan masalah psikologis remaja turut menyumbangkan masalah tersendiri bagi pembentukan dan pengembangan identitas etnik. Remaja yang mulai mengembangkan konteks komunikasinya di luar keluarga mengalami kebingungan dalam berbagai peran. Remaja yang mulai memberontak terhadap aturan keluarga, memposisikan lingkungan di luar keluarga sebagai rujukan dalam bersikap dan berperilaku. Lingkungan yang dimaksud meliputi lingkungan pertemanan sebaya di sekolah ataupun di masyarakat. Hal ini mendasari penelitian untuk mengetahui bagaimana peranan pertemanan di sekolah dalam pengembangan identitas etnik remaja transmigran Jawa di Lampung.

Dari berbagi interaksi yang dialami remaja dengan tahapan psikologis yang menyertai, preferensi identitas etnik remaja sebenarnya dapat merujuk pada salah satu atau kedua etnik orang tua remaja. Namun, hal ini belum sepenuhnya dapat dilakukan karena rendahnya kompetensi remaja terhadap budaya Jawa. Identitas etnik yang bukan semata-mata merujuk pada identitas budaya, membuat identitas etnik ini menjadi rumit bagi remaja di Lampung. Identitas etnik remaja transmigran bu- kan hanya mengacu pada pertalian darah dan budaya yang dirujuk dalam keluarga, akan tetapi juga berkaitan dengan migrasi keluarga dan kelompok etnik tersebut. Dalam konteks ini, individu (termasuk remaja) dapat memilih identitas etnik yang dikehendaki. Namun hal ini tidak dapat dilakukan secara serta merta tanpa disertai dengan ciri pendukung yang memadai. Dalam interaksi sosial dan komunikasi antarbudaya yang dialami remaja; yang disertai dengan minimnya pengetahuan, pengalaman, kemampuan serta motivasi sosial mengakibatkan remaja mengalami kebingungan dalam membentuk dan mengembangkan identitas etniknya. Lebih lanjut, pengembangan identitas etnik dapat dilakukan remaja melalui eksplorasi diri dan eksperimen peran. Ini dilakukan sebagai salah satu upaya remaja untuk menambah pengetahuan, kemampuan dan keahlian dalam interaksi sosial.

Siapapun yang ada di masyarakat memerlukan pengakuan sosial atas eksistensi dirinya dalam interaksi. Dari interaksi ini, individu dapat mengembangkan identitas dan potensi dirinya. Identitas ini melibatkan pandangan diri sendiri terhadap orang lain dan sebaliknya. Pertanyaan tentang identitas diri ini dapat diawali dari pertanyaan 'siapa saya'. Pertanyaan ini menjadi rumit, manakala definisi diri kita berbeda-beda apabila berinteraksi dengan orang yang berbeda. Hal ini mendasari penelitian oleh Martin dan Thomas (2004: 189) yang menyatakan bahwa identitas berhubungan dengan pertanyaan siapa kita manakala berinteraksi dengan orang lain. Hal ini berkaitan dengan penyataan diri yang oleh Steward (1993: 233) yang menyatakan bahwa identitas diri adalah sebuah proses pengungkapan diri sendiri secara verbal dan non verbal kepada orang lain tentang siapa dirinya. Minimnya pengalaman remaja terhadap interaksi sosial dan fokus perkembangan diri yang cenderung sejalan dengan perkembangan usia, menjadikan identitas diri menjadi yang yang sulit dan rumit bagi remaja, terlebih lagi identitas etnik. Bagi Martin dan Thomas (2004: 160), identitas etnik dimaknai sebagai seperangkat gagasan tentang keanggotaan dan kelompok etnik yang melibatkan danya beberapa dimensi, yaitu: (1) identifikasi diri, (2) pengetahuan tentang tradisi, kebiasaan, nilai dan perilaku etnik; (3) rasa memiliki. Lebih lanjut, identitas etnik sangat berhubungan erat dengan pengalaman 
seseorang terhadap kelompok budaya tertentu dan mengetahui segala sesuatunya yang diwariskan. Hal ini menempatkan keluarga sebagai kelompok utama dalam pembentukan identitas etnik, yang didukung dengan masyarakat pendukung budaya yang sama yang ada di sekitarnya.

Pemaparan di atas menegaskan bahwa remaja memerlukan lingkungan sosialnya untuk membentuk dan mengembangkan identitas dirinya, termasuk identitas etniknya. Lebih lanjut, identitas etnik merupakan hal yang melekat pada individu dalam kelompok budaya. Sedangkan untuk mengetahui identitas budaya dapat diketahui melalui cara pandang, orientasi berpikir, perasaan dan cara bertindak (Liliweri, 2005: 42). Hal ini termanivestasi dalam bahasa, yang menurut Champion (dalam Liliweri, 2005: 35) adalah sebagai identitas utama dari kelompok etnik. Dengan demikian, terdapat keterkaitan antara identitas dengan budaya, sebagaimana dinyatakan oleh Martin dan Thomas (2004: 1489):

Identity serve as a bridge between culture and communication. It is important because we communicate our identity to other, and we learn who we are through communication. It is through communication - with our family, friends and others - that we come to understand ourselves and form our identity. Issues of identity are particularly important in intercultural interaction.

Sebagai budaya yang secara jumlah pengikutnya dominan, kelompok etnik Jawa di Lampung merupakan kelompok budaya yang dapat dianggap sebagai kelompok mayoritas. Hal ini mempengaruhi pada bagaimana remaja generasi berikutnya dalam mengembangkan identitas etnik. Lebih lanjut, Martin dan Thomas (2008: 108-109) menyatakan bahwa tahapan pengembangan identitas etnik pada kelompok mayoritas, yaitu (1) unexamined identity; pada tahapan ini ditandai dengan kurangnya eksplorasi individu terhadap etnisitas, sehingga identitas yang muncul biasanya dipengaruhi oleh remaja dan teman; (2) Acceptance; pada tahap ini, remaja menerima dan menginternalisasi nilai-nilai yang ada di masyarakat tanpa rasa bingung dalam mengidentifikasi nilai dan norma yang dominan. Pada tahap ini, individu cenderung menghindar interaksi dengan kelompok yang dianggapnya minoritas; (3) Resistance, pada tahap ini remaja melakukan penguatan dan berupaya mendapatkan dukungan sosial melalui kelompok mayoritas, dan menganggap kelompok minoritas sebagai sumber masalah sosial. Meskipun remaja dapat mengembangkan sikap positif atau pun negatif, remaja pada tahapan ini cenderung mengembangkan sikap eksklusif yang diiringi dengan perubahan perilaku dan cenderung menghindari komunikasi dengan pihak yang dianggap bukan anggota kelompoknya; (4) redefinisi dan reintegrasi, merupakan tahapan yang lebih bersifat positif terhadap kelompok etniknya dan bahkan dengan kelompok etnik lainnya.

Dalam upaya pengembangan identitas etnik, remaja memerlukan penguatan nilai sosial yang positif, yang salah satunya dapat diperoleh dari pertemanan sebaya. Lebih lanjut, Kelly dan Hansen (dalam Desmita, 2007: 220-221) menyatakan bahwa fungsi pertemanan sebaya yaitu: (1) teman dapat mengontrol impuls positif; (2) teman memberikan dukungan emosional dan sosial, yang menjadikan remaja lebih mandiri dan mengurangi ketergantungan pada keluarga; (3) pertemanan dapat meningkatkan keterampilan sosial, mengembangkan kemampuan penalaran dan belajar mengekspresikan perasaan dengan cara yang lebih matang; (4) dalam pertemanan, remaja dapat mengembangkan sikap, tingkah laku dan peran terhadap seksualitas untuk menjadi laki-laki dan perempuan muda; (5) pertemanan dapat memperkuat penyesuaian dan membantu mengevaluasi moral serta nilai-nilai yang diterima, sehingga remaja dapat mengembangkan kemampuan penalaran dan moralnya; (6) pertemanan dapat meningkatkan harga diri remaja untuk dapat menjadi individu yang disukai oleh teman-temannya.

Hal di atas menegaskan bahwa selain keluarga, pertemanan dapat membantu remaja untuk mencapai kedewasaan, sehingga hal ini juga akan membantu remaja dalam berproses mencari identitas dirinya. Selain pertemanan, lingkungan sekolah juga memberikan kontribusi pada remaja dalam mewarnai dinamika perkembangan hubungan. Remaja juga berinteraksi dengan guru, yang juga dapat dijadikan salah satu rujukan dalam mengembangkan dan menetukan nilai-nilai sosial yang akan dianut dan dikembangkan remaja. Lebih lanjut, $\mathrm{S}$. Stanfeld Sargent (dalam Sarwono, 2009: 95- 
96) menyatakan bahwa sebagai lembaga masyarakat, sekolah juga memiliki fungsi untuk mewariskan kearifan budaya, bahasa, kemampuan baca tulis, aturan-aturan yang harus dipatuhi remaja yang berkaitan dengan pengembangan sikap positif serta pemberian sanksi untuk sikap dan perilaku negatif.

Pertemanan antarbudaya yang dialami remaja di Lampung memiliki kontribusi terhadap pengembangan identitas diri. Namun pertemanan antarbudaya ini perlu diteliti lebih lanjut, apakah petemanan antarbudaya juga memiliki kontrobisi bagi pengembangan identitas etnik remaja. Secara khusus, sensus penduduk Propinsi Lampung, BPS tahun 2000, menunjukkan bahwa etnik Jawa sebagai etnik pendatang menempati $\pm 60 \%$ dari total penduduk (dalam publikasi sensus penduduk, BPS 2010, tidak diperoleh jumlah data etnik di Lampung). Meskipun budaya jawa bukan budaya yang dominan, pendukung budaya Jawa merupakan mayoritas. Hal ini menjadi salah satu hal yang mendasari penelitian ini, mengenai budaya Jawa yang memiliki pengikut mayoritas akan tetapi tidak menjadi budaya dominan yang memberikan dinamika pada pengembangan identitas etnik remaja transmigran Jawa khususnya pada pertemanan remaja di sekolah dalam latar budaya majemuk. Pemilihan sekolah sebagai setting penelitian didasari pada pertimbangan berkembangan orientasi hubungan remaja, dan sekolah merupakan lingkungan yang memiliki peranan yang besar bagi pengembangan identitas diri remaja, selain keluarga.

Merujuk berbagai pendapat di atas, dan dikaitkan dengan kondisi di Lampung, maka penelitian ini terfokus pada bagaimana remaja transmigran Jawa mengembangkan identitas diri dan etniknya pada konteks pertemanan antar budaya di sekolah dalam latar budaya majemuk. Hal ini akan mengarahkan tujuan penelitian untuk menjelaskan dan menganalisa pertemanan lintas budaya remaja di sekolah yang berperan dalam pengembangan identitas diri dan etnik remaja transmigran Jawa di Lampung.

\section{METODE PENELITIAN}

Penelitian ini merupakan penelitian kualitatif dengan obyek penelitian terfokus pada bagaimana pertemanan lintas budaya remaja transmigran Jawa di sekolah dapat membantu remaja dalam mengembangkan identitas etniknya dalam latar budaya majemuk di Lampung. Subyek penelitian ini bersifat purposive (Spradely dalam Faisal. 1990: 57). Lebih lanjut, subyek penelitian ini yaitu remaja yang memiliki kriteria: (1) salah satu atau kedua orang tuanya beretnik jawa, (2) lahir dan besar di Lampung, (3) tinggal di lingkungan yang multi etnik, (4) memiliki lingkungan sekolah yang multietnik.

Pemilihan provinsi Lampung sebagai lokasi didasari pada kondisi bahwa Lampung sebagai wilayah tujuan transmigrasi sehingga menjadikan Lampung sebagai daerah multietnik. Kondisi ini juga akan dapat menggambarkan dinamika interaksi sosial remaja, khususnya dalam pertemanan. Lebih lanjut, untuk mendapatkan data penelitian yang relevan, fokus lokasi penelitian ini yaitu Kecamatan Ketapang, Kabupaten Lampung Selatan. Hal ini didasarkan pada pertimbangan diantaranya: (1) lokasi merupakan daerah multietnik, daerah tujuan transmigrasi langsung ataupun transmigrasi sisipan; dan (2) di lokasi terdapat sekolah yang dijadikan salah satu konteks interaksi remaja.

Data-data penelitian ini dikumpulkan melalui observasi partisipan dan wawancara mendalam terhadap remaja dan teman beda budayanya. Selanjutnya, data dianalisa melalui tahapan reduksi data, penyajian data dan verifikasi data (Moleong, 2005: 288). Lebih lanjut keabsahan data dilakukan peneliti dengan cara melakukan ketekunan pengamatan, perpanjangan waktu observasi dan triangulasi (Birowo, 2004: 5-8).

\section{HASIL DAN PEMBAHASAN}

Dinamika interaksi remaja di sekolah memiliki katerkaitan yang erat dengan upaya remaja dalam mengembangkan identitas diri, termasuk identitas etnik. Pengembangan identitas etnik ini diperlukan remaja agar eksistensi remaja dalam interaksi sosial dapat diakui, termasuk eksistensinya dalam kelompok. Secara umum, remaja memiliki kelompok pertemanan di masyarakat, baik dalam lingkup teman bermain di masyarakat ataupun di sekolah. Berdasarkan rentang usianya, secara umum, remaja di sekolah memiliki jumlah waktu interaksi yang lebih banyak dibandingkan dengan interaksinya dengan teman sepermainannya di masyarakat. Kondisi ini mendasari asumsi bahwa lingkungan di sekolah berikut pertemanan remaja di se- 
kolah dapat membantu remaja mencapai identitas diri ideal, termasuk identitas etnik.

Berdasarkan penentuan lokasi penelitian dan observasi lapangan, remaja yang di teliti berada di SMKN 1 Ketapang dan SMA Islam Maarif Pematang Pasir. Pertemanan yang terjalin yaitu pertemanan di kelas dan pertemanan di kegiatan ekstrakurikuler. Lebih lanjut, berdasarkan hasil pemetaan etnisitas di kedua sekolah, peneliti mendapatkan data bahwa sekolah tersebut memiliki karakteristik multietnik, terdiri dari remaja (menurut pengakuan) beretnik Jawa, Sunda, Bali, Bugis, Banten, Lampung, Padang, Palembang, Batak dan Semendo. Meskipun etnik Jawa mendominasi secara kuantitas, budaya jawa bukanlah budaya dominan di masyarakat Lampung. Kondisi ini juga terjadi di berbagai sekolah di Lampung. Secara khusus, kondisi lingkungan budaya ini akan dimanfaatkan remaja dalam upaya pengembangan identitas diri. Namun, karena tidak terdapat budaya etnisit yang dominan di sekolah, maka budaya tidak dapat secara maksimal menyandarkan pembentukan dan pengembangan identitas etnik para remaja di sekolah.

Secara umum, hasil penelitian menunjukkan bahwa terdapat sepuluh tema yang muncul dari pertemanan remaja di sekolah dalam pengembangan identitas diri, yang dapat dinyatakan sebagai berikut:

Tabel 10. 1 Tema Pertemanan Remaja di Sekolah dalam Pengembangan Identitas Diri

\begin{tabular}{cll}
\hline No & \multicolumn{1}{c}{ Tema } & \multicolumn{1}{c}{ Keterangan } \\
\hline $1 . \quad \begin{array}{l}\text { Alasan } \\
\text { pertemanan }\end{array}$ & a) $\begin{array}{l}\text { Kedekatan fisik (tempat duduk di kelas, jarak kelas dan tempat } \\
\text { tinggal) }\end{array}$ \\
& b) Kedekatan psikologis (usia, jenis kelamin, aspek personal dan \\
& emosional) \\
& c) Memiliki kesamaan hobi \\
& d) Memiliki kesamaan orientasi kegiatan (berada dalam ekstrakuri- \\
& e) Kuler yang sama) \\
& f) Jenis kelamin / gender
\end{tabular}

2. Konteks interaksi

- Konteks fisik
a) Ruang kelas
b) Teras kelas
c) Lapangan sekolah
d) Tempat parkir
e) Kantin
f) Mushola
g) Ruang guru
h) Perpustakaan

- Konteks waktu

Saat remaja berada di sekolah:
a) Sebelum jam pelajaran dimulai
b) Istirahat
c) Jam pelajaran kosong
d) Pulang sekolah
e) Setelah pulang sekolah (menunggu kegiatan ekstraskurikuler)

- Konteks relasi
a) Teman sekelas
b) Teman kegiatan ekstrakurikuler 

a) Membicarakan pelajaran sekolah (diskusi)
b) Membicarakan kegiatan sekolah (diskusi)
c) Merencanakan kegiatan
d) Bergosip dan membicarakan isi media massa
e) Basa Basi
f) Bercanda

3. Tema interaksi

4. Motivasi dan tu-
a) Basa basi
b) Mengakrabkan diri
c) Mengisi waktu luang
d) Mengembangkan diri (diskusi tugas)
e) Mendapatkan nilai pelajaran
f) Mendapatkan prestasi

g) Penyesuaian dan pengembangan diri sosial

h) Mendapatkan identitas kelompok dan afiliasi kelompok

i) Mencari dukungan sosial

j) Berbagi pengalaman

k) Kerjasama

1) Pengakuan orang lain

m) Eksistensi diri dalam interaksi

n) Aktualisasi diri
Tipe
aksi
a) Personal
b) Sosial

6. Situasi interaksi Formal, informal

Sikap yang cenderung dikem-

7. bangkan dalam in- a) Kompromis inferior teraksi

b) Kompromis superior

\section{Bahasa yang digu- a) Bahasa nasional}

8. nakan dalam inter- b) Bahasa jawa dalam kosakata yang terbatas
aksi
c) Bahasa teman dalam kosakata yang terbatas
9. Cara berkomuni-
a) Lugas
kasi
b) Tidak lugas

Identitas diri yang

10. dimunculkan saat interakasi a) Identitas sebagai siswa

b) Identitas sebagai anggota kelompok

c) Identitas etnik dengan menggunakan bahasa jawa sebagai pernyataan identitas etnik 
Pembentukan identitas etnik remaja di sekolah tidak dapat dipisahkan dari kesadaran remaja terhadap pembentukan identitas etniknya dalam keluarga. Sebagai salah satu agen sosialisasi di masyarakat, dan lembaga pendidikan formal, sekolah memiliki peranan untuk meneruskan nilai-nilai yang ada di masyarakat. Sekolah juga akan membantu remaja untuk mencapai pribadi yang unggul sebagaimana harapan (ideal self). Dinamika interaksi remaja di sekolah dapat memberikan pengalaman pada remaja yang berbeda dengan pengalamannya di keluarga. Perbedaan tersebut meliputi: lingkungan fisik, peran remaja (sebagai siswa, teman, sahabat) yang seimbang dari rata-rata usia dan tahapan psikologis, dan tujuan interaksi remaja di sekolah mewarnai dinamika interaksi remaja dalam mengembangkan identitas diri, termasuk identitas etnik.

Secara umum, selain di kelas, kecenderungan remaja memilih mitra komunikasi di kegiatan ekstrakurikuler. Beberapa kegiatan ektrakurikuler yang bisanya diikuti remaja yaitu pramuka, olah raga, kesenian serta keterlibatan dalam kegiatan ilmiah sekolah. Berbeda dengan pertemanan remaja di kelas yang dibentuk berdasarkan kedekatan tempat duduk dan kedekatan psikologis, pertemanan remaja di kegiatan ekstrakurikuler dibingkai oleh kesamaan hobi dan kesamaan orientasi kegiatan.

Interaksi yang dilakukan remaja bukan hanya antarbudaya, akan tetapi juga antargender dan antarkelas. Pola-pola interaksi yang dikembangkan dalam kelompok sesuai dengan kondisi lingkungannya, sehingga dalam interaksi kelompok, remaja akan mendapatkan pengalaman melalui pengembangan orientasi terhadap orang lain. Interaksi dalam kelompok dengan tingkat frekuensi dan kohesivitas yang cukup tinggi akan menimbulkan ikatan emosi. Saling keterikatan ini memudahkan anggota kelompok untuk saling mempengaruhi, karena antar anggota kelompok akan dapat memberikan saran untuk pemecahan masalah dengan jalan memberikan keleluasaan bagi anggotanya untuk mencurahkan perasaan khawatir, marah, dan ketakutan dengan permasalahannya. Dalam hal ini kelompok memberikan kebebasan untuk saling memberi dan menerima, sehingga kelompok berperan sebagai sarana untuk belajar mengembangkan peran-peran sosialnya. Bagi remaja, kepercayaan dan sikap saling memahami akan dapat membantu seseorang untuk menemukan dan mengembangkan identitas diri, kepercayaan serta kebanggaan diri. Adanya frekuensi interaksi yang tinggi akan dapat meningkatkan kecenderungan kohesi diantara anggota kelompok. Lebih lanjut, interaksi remaja dalam pertemanan memiliki banyak motivasi dan tujuan.

Hasil penelitian menunjukkan bahwa tema interaksi remaja di sekolah dapat digolongkan dalam tiga kategori yaitu: (1) membicarakan (diskusi) tentang pelajaran dan tugas-tugas sekolah; (2) membicarakan (berdiskusi) tentang kegiatan ekstrakurikuler dan kegiatan sekolah lainnya; atau (3) sekedar basa-basi, bercanda dan bergosip. Lebih lanjut interaksi remaja dalam pertemanan di sekolah dibingkai dalam motif personal dan sosial, yang terjabarkan dalam empat belas tujuan interaksi. Tujuan interaksi remaja dalam pertemanan di sekolah, yaitu: (1) basa basi; (2) mengakrabkan diri; (3) mengisi waktu luang, (4) mengembangkan diri (diskusi tugas), (5) mendapatkan nilai pelajaran, (6) mendapatkan prestasi, (7) penyesuaian dan pengembangan diri sosial, (8) mendapatkan identitas kelompok dan afiliasi kelompok, (9) mencari dukungan sosial, (10) berbagi pengalaman, (11) kerjasama, (12) pengakuan orang lain, (13) eksistensi diri dalam interaksi, dan (14) aktualisasi diri.

Beragamnya tema, motivasi dan tujuan interaksi remaja dalam pertemanan, menegaskan bahwa pertemanan memiliki peranan yang sangat besar bagi pengembangan diri remaja. Kesamaan ciri-ciri yang ada pada remaja akan memberikan penguatan dalam pembentukan identitas diri. Remaja yang berada dalam masa transisi, memiliki tugas untuk menyongsong masa dewasa yang memerlukan dukungan kematangan psikologis. Salah satu hal yang harus remaja lalui yaitu menyelesaikan permasalahan krisis yang terjadi dalam dirinya, termasuk krisis identitas diri dalam peran-peran sosialnya.

Selain pengembangan identitas diri, secara umum remaja lebih mengembangkan identitas kelompok dengan mencari persamaan dengan teman-temannya. Hal ini dilakukan remaja sebagai upayanya untuk menyalurkan keinginan dan mencapai peran-peran sosial yang tidak diperoleh di keluarga. Pengembangan peran remaja dengan dukungan mitra komunikasi yang sebaya, memposisikan remaja untuk dapat mengeksplorasi potensi dirinya secara maksi- 
mal. Dalam kelompok teman sebaya, remaja juga mendapatkan perangkat nilai dan sistem etis sebagai pegangan sikap dan perilaku remaja untuk mengembangkan ideologinya. Lebih lanjut, interaksi remaja dengan teman sebayanya dilakukan sebagai salah satu upaya untuk mengembangkan hubungan yang lebih matang dengan didukung adanya kemandirian secara emosional dengan tidak sepenuhnya tergantung pada orang tua dan orang dewasa lainnya.

Meskipun pengembangan identitas di sekolah secara langsung belum mengarah identitas etnik, secara implisit peneliti menemukan adanya kontribusi komunikasi antarbudaya dalam interaksi remaja dengan dengan mitra komunikasinya terhadap pengembangan identitas diri dalam kelompok. Lebih lanjut, interaksi antarbudaya yang dialami remaja memberikan tambahan pengalaman tentang cara berempati dengan teman yang berbeda budaya melalui pengenalan budaya lain. Pengenalan ini dilakukan remaja sebagai upaya untuk mempererat persamaan dalam kelompok sehingga upaya ini akan meningkatkan kohesivitas. Dalam beberapa interaksi, peneliti menjumpai upaya remaja untuk mengenal bahasa Bugis untuk merujuk pada beberapa aktivitas bersama. Penggunaan bahasa etnik lain dalam interaksi dilakukan remaja sebagai bukti kedekatan hubungan pertemanan di kelas.

Hasil observasi, remaja Jawa menggunakan beberapa kata dalam: (1) bahasa Bugis, seperti kata mandre (makan), lao (pergi) dan lisu (pulang); (2) bahasa Sunda, seperti kata naon (apa); atau (3) bahasa Lampung api (apa) dalam dialek khusus; serta sebaliknya, peneliti juga menjumpai teman remaja yang menggunakan bahasa Jawa dalam kosakata terbatas juga untuk menunjukkan kedekatannya. Beberapa remaja menyatakan bahwa penggunaan kosa kata etnik lain ini tidak digunakan untuk menunjukkan identitas etniknya, akan tetapi sebagai bukti kedekatan secara personal. Didukung data observasi dan wawancara, dari interaksi remaja yang menggunakan kosa kata terbatas dari etnik teman yang dianggapnya berbeda budaya, justru ditujukan untuk menunjukkan perbedaan budaya. Misalnya teman remaja yang beretnik Bali, sering berinteraksi menggunakan bahasa Jawa dalam menunjukkan bahwa pengembangan, penyataan dan pengakuan identitas etnik remaja justru muncul pada saat situasi interaksi yang tidak formal. Hal ini dikarenakan interaksi formal lebih banyak dicurahkan pada saat proses belajar di sekolah berlangsung.

Penggunaan bahasa teman dalam kosa kata yang terbatas ini biasanya dilakukuan oleh remaja keturunan etnik Jawa yang memiliki sikap superior kompromis yang dikembangkan dalam interaksi. Remaja yang superior kompromis ini cenderung berinteraksi secara lugas. Hal yang sebaliknya, remaja keturunan etnik Jawa yang mengembangkan sikap kompromis inferior dalam interaksi, yang cenderung berinteraksi secara tidak lugas. Sikap inferior yang dikembangkan remaja keturunan etnik Jawa dalam interaksi memberika peluang kesempatan bagi temannya yang beretnik non-Jawa untuk menggunakan beberapa kata dalam bahasa Jawa untuk berinteraksi.

Berdasarkan hasil klarifikasi melalui wawancara, dua kondisi yang kontradiktif ini terjadi karena pertama, remaja yang bersifat superior konfromis cenderung mengembangkan cara berkomunikasi yang lugas merasa diberi kebebasan untuk bisa lebih adaptif dengan mitra komunikasi. Dihadapkan pada teman yang beretnik Bugis atau Lampung (yang cenderung berkomunikasi secara lugas) menempatkan remaja transmigran Jawa merasa tidak sungkan jika terjadi salah pengucapan. Justru penguasaan remaja terhadap beberapa kosa kata, bukan hanya menunjukkan kedekatan, akan tetapi dalam beberapa situasi peneliti menjumpai kondisi ini digunakan oleh remaja transmigran Jawa untuk memaksa secara halus mitra interaksinya untuk mengikuti maunya. Contohnya, remaja transmigran Jawa menggunakan kata mandre (bahasa Bugis: makan) dalam logat Jawa untuk membujuk temannya yang beretnik Bugis agar mau menemaninya ke kantin. Dalam beberapa situasi, cara ini terbukti efektif. Terkonfirmasi dengan teman remaja beretnik bugis, penggunaan kata mandre membuatnya merasa tidak tega, bukan hanya karena temannya yang lapar, akan tetapi tidak tega karena upaya menggunakan bahasa bugis dimaknainya sebagai kedekatan yang harus diperhatikan secara khusus. Didukung data hasil penelitian, remaja superior-konfromis cenderung memilih teman beretnik Bugis atau Lampung karena merasa nyaman berinteraksi secara lugas. 
Kedua, remaja yang bersifat kompromis inferior, biasanya mengembangkan cara berkomunikasi secara tidak lugas, yang cenderung memiliki rasa tidak nyaman jika salah untuk menggunakan bahasa etnik temannya (non Jawa) dalam interaksi. Cara komunikasi yang tidak lugas ini justru tidak memberikan keleluasaan dan keberanian remaja transmigran jawa untuk menggunakan bahasa temannya (non Jawa) dalam interaksi. Kondisi ini memunculkan mekanisme kompromi / adaptasi dalam interaksi, yaitu teman remaja Jawa menggunakan kata / kalimat dalam bahasa Jawa. Terkonfirmasi dalam wawancara, teman remaja transmigrasi Jawa yang beretnik Bali bisa menguasai bahasa Jawa karena terdapat beberapa persamaan kosa kata dan remaja Bali ini tinggal di lingkungan etnik Jawa. Kondisi ini juga terjadi pada interaksi remaja transmigran jawa dengan temannya yang beretnik Sunda. Kondisi ini mempertegas hasil penelitian sebelumnya, bahwa remaja transmigran Jawa cenderung memilih teman yang memiliki cara berkomunikasi yang sama. Lebih lanjut dinyatakan bahwa teman remaja transmigran Jawa yang beretnik Bali san Sunda sama-sama mengembangkan sikap komunikasi yang tidak lugas.

Bagi remaja transmigran Jawa yang mengijinkan penggunaan bahasa Jawa dalam interaksinya karena ia menganggap itu sebagai suatu bentuk kedekatan. Seandainya terdapat salah pengucapan, baginya (remaja transmigran Jawa) akan bisa memakluminya karena temannya tidak beretnik Jawa. Adanya perbedaan sikap remaja transmigran Jawa dalam penggunaan bahasa non Jawa dalam interaksi bukan karena ketidakmampuannya, akan tetapi lebih pada upaya penghormatan terhadap budaya lain.

Lebih lanjut, dua kondisi interaksi di atas dilakukan remaja pada waktu luang (saat santai, jam pelajaran kosong, jam istirahat), dalam berbagai tema interaksi serta dilakukan untuk berbagai tujuan interaksi. Lebih lanjut, suasana keakraban antarbudaya ini terjadi pada remaja yang memiliki intensitas interaksi yang tinggi karena kedekatan fisik tempat duduk atau kedekatan psikologis/ personal. Di sisi lain, interaksi remaja dengan teman ekstrakurikuler antarbudaya, juga dibingkai dalam interaksi antar-kelas, antar-jenis kelamin. Intensitas kegiatan ekstrakurikuter yang tidak sebanyak di kelas, memposisikan pemilihan temannya didasarkan pada kesamaan hobi dan orientasi kegiatan yang sama. Tema-tema yang dalam interaksi di kegiatan ekstrakurikuler lebih terbatas pada upaya remaja untuk mengembangkan aktualisasi diri melalui kegiatan dan cenderung dibingkai dalam suasana interaksi yang formal. Hasil observasi menunjukkan bahwa interaksi remaja di kegiatan ekstrakurikuler lebih banyak menggunakan bahasa nasional. Peneliti jarang menjumpai remaja ataupun temannya menggunakan bahasa Jawa atau pun non Jawa dalam interaksi. Terkonfirmasi melalui wawancara, remaja dan temannya menyatakan bahwa: (1) waktu kegiatan ekstrakurikuler yang sedikit, menjadikan remaja lebih terfokus pada kegiatan daripada interaksi sosial yang terjadi; (2) motivasi interaksi yang dikembangkan remaja dalam setting ini adalah untuk mengembangkan diri, sehinga tema-tema interaksi lebih mengarah ke hal-hal yang bersifat formal seperti membicarakan rencana kegiatan yang akan dilakukan, dan tindak lanjut dari kegiatan tersebut. Secara khusus (3) terbatasnya pengetahuan remaja dan temannya terhadap kosa kata dalam bahasa Jawa ataupun non Jawa, menjadikan penggunaan bahasa nasional lebih dianggap efektif menjembatani perbedaan budaya yang ada.

Pengembangan identitas etnik remaja transmigran Jawa dalam pertemanan antarbudaya di sekolah berhubungan erat dengan dua hal, yaitu identifikasi diri dan pengetahuan tentang budaya rujukan yang diperoleh remaja di keluarga. Pertama, hasil penelitian menunjukkan bahwa identifikasi remaja transmigran Jawa terhadap dirinya lebih banyak disandarkan pada identitas yang lebih bisa memberinya atribut yang jelas dan kepastian dalam bersikap serta berperilaku sesuai dengan norma universal di masyarakat. Temuan di lapangan menunjukkan bahwa remaja lebih membingkai dirinya dalam identitas berdasarkan agama; jenis kelamin; siswa; posisi dalam keluarga (misal: anak tertua); identitas orang tua (misal: anak petani); hobi (misal: suka bermain bola); pengalaman dan pengharapan (misal: pernah tinggal di pondok, pernah tinggal di beberapa daerah; jarang bertemu ayah); dan sifat-sifat yang dirasa ada pada dirinya, seperti periang, pendiam, sederhana. Tidak dijumpainya iden- 
titas etnik pada remaja menunjukkan bahwa remaja masih mengalami kebingungan dalam menentukan identitas etniknya. pada tahapan identitifikasi diri ini, remaja transmigran Jawa berada dalam tahapan unexamined identity.

Kedua, pengetahuan remaja tentang budaya rujukan berhubungan dengan budaya yang dikembangkan di keluarga. Lebih lanjut, selain bahasa Jawa Ngoko, remaja merasa tidak mengerti dan memahami budaya Jawa. Hal ini dikarenakan remaja memiliki tingkat keterlibatan yang rendah dalam setiap ritual budaya di keluarga. Penelitian menunjukkan bahwa remaja transmigran Jawa cenderung menganggap budaya Jawa banyak aturan, ribet, kuno, sarat nilai, banyak sesaji, dan berhubungan dengan tahyul. Pengetahuan dan pemahaman remaja transmigran Jawa yang bersifat negatif ini juga menjadi kendala bagi remaja untuk membentuk dan mengembangkan identitas etniknya. Hasil wawancara, mayoritas remaja transmigran Jawa ingin memiliki identitas etnik sebagai etnik Jawa karena: (1) etnik Jawa dominan sebagai penduduk (jumlah mayoritas); (2) etnik Jawa bisa diterima di berbagi kalangan, baik di masyarakat maupun lingkungan kerja; (3) bahasa Jawa sudah marak digunakan dalam interaksi keseharian. Meskipun terdapat dominasi bahasa Jawa di masyarakat, hal ini tidak menunjukkan budaya Jawa sebagai budaya yang dominan, karena nilai-nilai Budaya Jawa hanya dikembangkan oleh masyarakat pendukungnya, tidak oleh kelompok etnik lain.

Kedua penentu identitas etnik diatas seolah bertolak belakang. Remaja transmigran Jawa tidak mengidentifikasikan dirinya beretnik Jawa, akan tetapi memosisikan identitas etnik Jawa sebagai identitas tujuan. Secara khusus, pengembangan dan penguatan identitas etnik remaja transmigran Jawa di sekolah dapat terjadi dalam pertemanan satu etnik. Hal ini hanya dapat dibuktikan dengan penggunaan bahasa Jawa ngoko dalam interaksi pertemanan satu etnik, tanpa didukung dengan penguasaan budaya Jawa lainnya. Apabila bahasa dijadikan rujukan dalam penetuan identitas etnik; remaja transmigran Jawa akan mengalami kebingungan manakala dihadapkan pada pernyataan "siapa menggunakan bahasa Jawa dalam interaksi adalah etnik Jawa". Menyikapi hal ini, remaja transmigran Jawa men- ganggap bahwa identitas etnik memang dapat dilihat dari bahasa yang digunakan. Akan tetapi lebih lanjut, identitas etnik ini juga harus didukung dengan penerapan budaya yang dirujuk dalam kehidupan keseharian. Terkait peran keluarga, penerapan budaya yang dirujuk berkaitan dengan pertalian darah yang dimiliki. dengan demikian identitas etnik didasarkan pada keturunan dan budaya yang dikembangkan dan diwariskan dalam keluaraga. Hal ini terjadi karena remaja transmigran Jawa tidak memiliki identitas etnik alternatif yang dapat dijadikan bahan untuk pengembangan identitas etnik. Meskipun remaja transmigran Jawa lahir di Lampung, secara tegas mereka menolak jika dikatakan dirinya Lampung. Kondisi ini muncul dikarenakan remaja transmigran Jawa menganggap: (1) budaya Jawa berbeda dengan budaya Lampung; (2) meskipun belum tergali maksimal, pengetahuan dan pengalaman budaya Jawa dapat diperoleh di keluarga; (3) merasa lebih nyaman mengaku beretnik Jawa, meskipun pengetahuan budaya Jawa sangat minim.

Dengan kondisi penguasaan budaya dan sumber daya yang dimiliki, remaja transmigran meneruskan nilai-nilai budaya yang didapatnya dari keluarga sebagai bahan untuk berinteraksi dalam pertemanan. Kondisi ini menunjukkan bahwa lingkungan di sekitar remaja mempengaruhi remaja dalam mengembangkan identitas dirinya, berikut cara pandangnya terhadap dirinya dan orang lain.

Kondisi di atas menggambarkan bahwa pencapaian pengembangan identitas remaja, termasuk identitas etnik di sekolah masih berada dalam suatu proses yang bersifat progresif menuju ke identitas etnik yang diinginkan. Karena berkembangnya lingkungan interaksi remaja dan banyaknya peran baru dalam interaksi, kondisi ini menyebabkan remaja belum memprioritaskan identitas etniknya.

Pengembangan identitas diri remaja di sekolah dipengaruhi oleh pengetahuan dan pengalaman yang remaja peroleh dari keluarga, pola asuh dan pola komunikasi dalam keluarga akan memberikan rujukan bagi remaja dalam mengembangkan interaksi antarbudaya di sekolah. Kurang maksimalnya pengembangan identiktas etnik remaja dalam pertemanan antarbudaya di sekolah menunjukkan bahwa remaja transmigran Jawa dan teman-temannya 
lebih mementingkan identitas kelompok (yang anggota yang berbeda budaya) menempatkan remaja pada posisi untuk lebih mendukung penguatan eksistensi di kelompoknya. Kondisi ini didukung dengan tidak adanya tuntutan bagi remaja untuk menampilkan identitas etniknya, sebagaimana di keluarga.

Suasana interaksi antarbudaya yang remaja alami di sekolah, yang berbeda dengan keluarga, membantu remaja untuk mengembangkan peran-peran sosialnya. Dengan mengenal budaya lain, remaja akan memiliki beberapa rujukan nilai budaya pembanding dengan budaya yang diperoleh dari keluarganya. Dalam beberapa kasus, pada posisi ini, mendukung remaja untuk cenderung mengalami kebingungan karena adanya benturan nilai antarbudaya yang diperoleh di sekolah dengan keluarga.

Secara khusus, terkait perteman antarbudaya di sekolah, remaja transmigran Jawa mendapatkan dukungan pengembangan identitas relasi dan kelompok yaitu (1) penguatan identitas kelompok yang didasarkan pada relasi remaja saat kegiatan ekstrakurikuler yang memiliki ciri khusus dengan jumlah peserta sedikit dan dipandang eksklusif; (2) adanya upaya remaja untuk mengenal dan budaya lain untuk menunjukkan kedekatan diantara mereka. Lebih lanjut, hal ini akan mempengaruhi pandangan dan penilaian remaja terhadap dirinya, budayanya, orang lain dan budaya lain.

Lingkungan fisik sekolah dengan peran sosial remaja sebagai siswa, menjadikan remaja tidak dapat secara maksimal mengembangkan identitas etniknya. Kondisi ini terjadi karena remaja transmigran Jawa dan temannya sama-sama memiliki pengetahuan yang minim tentang budayanya masing-masing. Tidak adanya figur yang ideal dalam pengembangan identitas etnik di sekolah, mendorong remaja dan temannya untuk mengembangkan budayanya sendiri dalam interaksi, yang bergantung pada peran, nilai tawar diri dan superioritas yang terbangun dalam interaksi. Namun secara umum, rendahnya kesadaran termaja terhadap identitas etniknya, menjadikan remaja cendeurng adaptif dan merujuk budaya netral yang terbangun dalam interaksi.

Dalam pertemanan antarbudaya yang dialami remaja di sekolah, remaja memandang pertemanannya sebagai wahana untuk mendapatkan dukungan sosial, baik sebagai teman bicara, berbagi pengalaman, membantu memecahkan beberapa permasalahan, baik permasalahan tugas-tugas sekolah ataupun permasalahan lainnya. Persamaan rentang usia dan kecenderungan psikologis yang relatif sama, mendukung remaja untuk membuat kelompok-kelompok kecil yang secara umum membantu remaja dalam melewati masa-masa krisis identitas dan sekaligus sebagai tempat untuk mengembangkan diri dari peran-peran sosialnya

\section{SIMPULAN}

Hasil penelitian menunjukkan bahwa pengembangan diri remaja transmigran Jawa dalam pertemanan antarbudaya di sekolah didasarkan pada sepuluh tema utama, yaitu terdapat (1) eman alasan memilih teman, (2) tiga konteks interaksi; (3) lima tema interaksi; (4) empat belas motivasi dan tujuan interaksi; (5) dua tipe motif interaksi; (6) dua situasi interaksi; (7) dua sikap yang dikembangkan, (8) tiga bahasa yang digunakan dalam interaksi, (9) dua cara berkomunikasi; dan (10) tiga identitas diri yang dimunculkan dalam pertemanan di sekolah.

Pengembangan identitas etnik remaja transmigran Jawa dalam pertemanan antarbudaya di sekolah dapat dikenali dari sikap yang dikembangkan dalam interaksi. Remaja transmigran Jawa yang kompromis inferior memiliki cara adaptasi dalam pertemanan antar budaya yang berbeda dengan remaja transmigran Jawa yang kompromis-superior.

Pengembangan identitas etnik remaja transmigran Jawa dalam pertemanan antarbudaya di sekolah berada dalam tahapan unexamined identity, dan pertemanan remaja transmigran Jawa di sekolah belum memberikan kontribusi yang maksimal dalam pengembangan identitas etnik.

Penelitian ini memberikan saran bahwa: mengingat pentingnya identitas diri dan identitas etnik dalam interaksi sosial, maka perlu dikaji tentang kompetensi remaja, orang tua, keluarga dan masyarakat terhadap budaya rujukan penentu identitas etnik. Hal ini didasarkan pada minimnya pengetahuan dan pengalaman budaya remaja transmigran Jawa yang dijadikan rujukan dalam interaksi sosial. 


\section{DAFTAR PUSTAKA}

Birowo, A. (2004). Metode penelitian komunikasi. Jogjakarta: Gitanyali

Desmita. (2007). Psikologi perkembangan. Bandung: Remaja Rosda Karya

Faisal, S. (1990). Penelitian kualitatif, dasar dan aplikasi. Malang: Yayasan Asah Asih Asuh.

Liliweri, A. (2005). Prasangka dan konflik komunikasi lintas budaya masyarakat multikultur. Yogjakarta: LkiS

Martin, J. N.; Nakayama, T. K. (2004). Intercul- tural communication in context. New York: Mc Graw Hill

(2008). Experiencing intercultural communication: an introduction, $3^{\text {th }}$ edition. New York: Mc Graw Hill

Moleong, L. J. (2005). Metode penelitian kualitatif. Bandung: Remaja Rosdakarya.

Sarwono, S. W., Meinarno, E. A., dkk. (2009). Psikologi sosial. Jakarta: Salemba Humanika

Stewart, J. \& Logan, C. (1993). Together communicating interpersonally $4^{\text {th }}$ edition. New York: McGraw-Hill Inc 